\title{
Marten Breuer
}

\section{Staatshaftung für judikatives Unrecht}

Eine Untersuchung zum deutschen Recht, zum Europa- und Völkerrecht

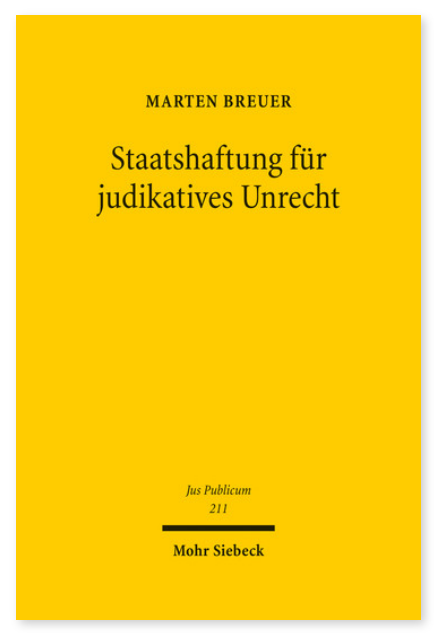

2011. XXVIII, 726 Seiten. JusPubl 211

ISBN 978-3-16-151762-4

DOI 10.1628/978-3-16-151762-4

eBook PDF 159,00€

ISBN 978-3-16-150535-5

Leinen $159,00 €$
Die Frage nach der Staatshaftung für judikatives Unrecht betrifft eine besonders komplexe Thematik. Einerseits besteht offenkundig die Gefahr, durch Zulassung der Haftung des Staates (nicht des Richters als Individuum) für behauptete richterliche Fehlentscheidungen den regulären Instanzenzug zu unterlaufen und einen »regressus ad infinitum" zu eröffnen. Andererseits sehen sowohl die deutsche als auch die meisten europäischen Rechtsordnungen in gewissen Fallkonstellationen eine Haftung für judikatives Unrecht vor. Erforderlich ist daher ein dogmatisches Modell, das Grund und Grenzen der Staatshaftung für judikatives Unrecht zu bestimmen vermag. Marten Breuer entwirft dieses Modell zunächst für die deutsche Rechtsordnung und untersucht anschließend dessen Übertragbarkeit auf das Europa- und Völkerrecht. Hierdurch erfährt die Thematik erstmals eine rechtsordnungsübergreifenden Analyse.

Marten Breuer Geboren 1971; Studium der Rechtswissenschaft in Würzburg; 2000 Promotion; 2010 Habilitation; seit 2012 Inhaber des Lehrstuhls für Öffentliches Recht mit internationaler Ausrichtung an der Universität Konstanz.

Jetzt bestellen:

https://mohrsiebeck.com/buch/staatshaftung-fuer-judikatives-unrecht-9783161517624?no_cache=1 order@mohrsiebeck.com

Telefon: +49 (0)7071-923-17

Telefax: $+49(0) 7071-51104$ 